\title{
Effectiveness of Calcium Nitrite in Retarding Corrosion of Steel in Concrete
}

\author{
L. Abosrra, ${ }^{1)}$ M. Youseffi, $^{1)}$ and A. F. Ashour ${ }^{2}$ \\ (Received March 17, 2011, Revised May 31, 2011, Accepted May 31, 2011)
}

\begin{abstract}
Corrosion of steel bars embedded in concrete admixed with $0 \%, 2 \%$ and $4 \%$ calcium nitrite $(\mathrm{CN})$, having compressive strengths of 20 and $46 \mathrm{MPa}$ was investigated. Reinforced concrete specimens were immersed in $3 \% \mathrm{NaCl}$ solutions for 1,7 and 15 days where $0.4 \mathrm{~A}$ external current was applied to accelerate the chemical reactions. Corrosion rate was measured by retrieving electrochemical data via potentiodynamic polarization technique. Pull-out tests of reinforced concrete specimens were then conducted to assess the corroded steel-concrete bond characteristics. Experimental results showed that corrosion rate of steel bars and steel-concrete bond strength were dependent on concrete strength, amount of $\mathrm{CN}$ added and accelerated corrosion period. As concrete strength increased from 20 to $46 \mathrm{MPa}$, corrosion rate of embedded steel decreased. The addition of $2 \% \mathrm{CN}$ to concrete of $20 \mathrm{MPa}$ was not effective in retarding corrosion of steel at long time of exposure. However, the combination of higher strength concrete and $2 \%$ or $4 \% \mathrm{CN}$ appear to be a desirable approach to reduce the effect of chloride-induced corrosion of steel reinforcement. After 1 day of corrosion acceleration, specimens without $\mathrm{CN}$ showed higher bond strength in both concrete mixes than those with $\mathrm{CN}$. After 7 and 15 days of exposure, the higher concentration of $\mathrm{CN}$, the higher bond strength in both concrete mixes achieved, except for the concrete specimen of $20 \mathrm{MPa}$ compressive strength with $2 \% \mathrm{CN}$ that recorded the highest deterioration in bond strength at 15 days of exposure.
\end{abstract}

Keywords: concrete, steel reinforcement corrosion, bond strength, polarization, chloride, calcium nitrite.

\section{Introduction}

Steel reinforcement in concrete structures is normally under passive condition against corrosion due to a thin iron oxide layer that forms on steel surface in high alkaline media of concrete. ${ }^{1,2}$ However, steel corrosion can be activated when chloride ions accumulate at the depth of steel and may cause localized breakdown of the passive film. After initiation of corrosion process, corrosion products (i.e. rust) involving a volume several times larger than that of original iron lead to internal stresses that result in cracking, splitting of concrete cover and loss of bond between steel rebar and concrete. ${ }^{3-5}$

A number of protection systems have been proposed to prevent or mitigate reinforced concrete from corrosion. ${ }^{6,7}$ Among the available methods, the use of nitrites, for example calcium nitrite (CN), as an admixture for new concrete can offer a simple and cost effective method to stop or delay chloride-induced corrosion. ${ }^{7-11}$ In addition, $\mathrm{CN}$ does not have any adverse effect on concrete properties due to its compatibility with hydration of cement and concrete. ${ }^{11,12}$ Nitrites are anodic inhibitors of corrosion and

\footnotetext{
${ }^{1)}$ School of Engineering, Design and Technology, University of Bradford, Bradford, West Yorkshire, BD7 1DP, UK.

${ }^{2)}$ School of Engineering, Design and Technology, University of Bradford, Bradford, West Yorkshire, BD7 1DP, UK.

Email : a.f.ashour@bradford.ac.uk.

Copyright (c) 2011, Korea Concrete Institute. All rights reserved, including the making of copies without the written permission of the copyright proprietors.
}

when added to reinforced concrete they are absorbed on the surface of steel acting as strong oxidizing passivators, enhancing the oxide layer and protecting the steel surface. They react with ferrous ions released from steel to form ferrous oxide $\left(\mathrm{Fe}_{2} \mathrm{O}_{3}\right)$ that is then converted to more stable ferric oxide $(\mathrm{FeOOH})$ as shown by the following equations ${ }^{13,14}$ :

$$
2 \mathrm{Fe}^{2+}+2 \mathrm{OH}^{-}+2 \mathrm{NO}^{2-} \rightarrow 2 \mathrm{NO} \uparrow+\mathrm{Fe}_{2} \mathrm{O}_{3}+\mathrm{H}_{2} \mathrm{O}
$$

Or

$$
\mathrm{Fe}^{2+}+\mathrm{OH}^{-}+\mathrm{NO}^{2-} \rightarrow \mathrm{NO} \uparrow+\gamma-\mathrm{FeOOH}
$$

Several researchers ${ }^{11,15,16}$ concluded that nitrite inhibitor is very effective in mitigating chloride-induced corrosion in reinforced concrete, reducing the corrosion rate as well as increasing the time for corrosion initiation. Al-Moudi et al. ${ }^{15}$ reported that concrete with $2 \%$ and $4 \% \mathrm{CN}$ inhibitor based on weight of cement did not show any corrosion initiation after 122 days when concrete immersed in $0.8 \% \mathrm{Cl}$ solution, or exposed to seawater. In another study with relatively low strength concrete exposed to $3.5 \% \mathrm{NaCl}$ wetting/drying cycles for 3 years, $2.5 \% \mathrm{CN}$ was effective in delaying corrosion initiation. ${ }^{12}$ However, Trepanier et al. ${ }^{17}$ concluded that $\mathrm{CN}$ was only effective in delaying corrosion but not after the initiation of corrosion. Al-Mehthel et al. ${ }^{18}$ applied wetting/drying cycles and impressed current techniques to expedite the corrosion propagation on reinforced concrete mixed with and without $\mathrm{CN}$ and contaminated with chlorides. They found that the impressed 
current method can be utilized for quick screening of the efficiency of corrosion inhibitor in reinforced concrete contaminated with chloride ions and also concluded that $\mathrm{CN}$ increased the time of initiation for steel reinforcement corrosion and concrete cracking.

So far, there is no data available regarding $\mathrm{CN}$ effect on corroded steel-concrete bond characteristics. In the present investigation, a series of experiments on corrosion and pull-out tests were conducted to examine the efficiency on various concentrations of $\mathrm{CN}$ on corrosion of steel bars embedded in concrete specimenshaving $20 \mathrm{MPa}$ and $46 \mathrm{MPa}$ compressive strength after 1, 7 and 15 days of corrosion acceleration in $3 \% \mathrm{NaCl}$ solution.

\section{Expermental program}

\subsection{Material and specimen preparation}

The constituent materials consisted of Portland cement, sand, $20 \mathrm{~mm}$ maximum size coarse aggregate and distilled water. Mix proportion and compressive strength of concrete obtained from testing $150 \mathrm{~mm}$ cubes are given in Table 1 , whereas the mechanical properties of steel reinforcement used are given in Table 2 . Test specimens consisted of a $12 \mathrm{~mm}$ diameter steel bar embedded in $150 \mathrm{~mm}$ concrete cubes. In order to ensure the bond slip failure would dominate over other types of failure such as yielding of steel reinforcement, only a short length of steel bars was embedded in concrete. The embedment length chosen was 5 times the bar diameter $(60 \mathrm{~mm})$. The concrete specimens were kept in moulds, covered with wet cloths at $23 \pm 2{ }^{\circ} \mathrm{C}$ for 3 days, then demolded and kept in a standard curing room of humidity $60 \pm 5 \%$ at $20 \pm 2^{\circ} \mathrm{C}$ for the following 25 days before testing. $30 \%$ by weight $\mathrm{CN}$ solutions were admixed with concrete to evaluate their effectiveness on retarding corrosion of steel rebar in concrete exposed to $3 \% \mathrm{NaCl}$. Dosages of $2 \%$ and $4 \% \mathrm{CN}$ (based on cement weight) were added to each concrete mix. The same compressive
Table 2 Mechanical properties of mild steel.

\begin{tabular}{c|c|c|c}
\hline Type & $\begin{array}{c}\text { Yield strength } \\
(\mathrm{MPa})\end{array}$ & $\begin{array}{c}\text { Tensile strength } \\
(\mathrm{MPa})\end{array}$ & $\begin{array}{c}\text { Young modulus } \\
(\mathrm{GPa})\end{array}$ \\
\hline \hline Grade 500 & 505 & 652 & 205 \\
\hline
\end{tabular}

strengths of concrete containing $\mathrm{CN}$ were also achieved after 22 days of curing.

\subsection{Corrosion acceleration and testing procedure}

The reinforced concrete specimens were immersed in $3 \% \mathrm{NaCl}$ solution. The solution tank was filled up to the top of concrete surface and external current of $0.4 \mathrm{~A}$ intensity was applied to accelerate the corrosion process in order to meet the study objectives within a reasonable time schedule. It is also to be noted that the impressed current creates a more uniform corrosion along both the length and circumference of the steel bar than a typical half-cell reaction. ${ }^{19,20}$ The impressed current direction was adjusted such that the reinforcing steel bar served as the anode while a graphite rod (counter electrode) was positioned in the tank to act as a cathode. A schematic representation of the electrochemical test set up is shown in Fig. 1. In order to establish different levels of steel reinforcement corrosion, accelerated corrosion time was extended over 1, 7 and 15 days. The corrosion rates were measured based on anodic current density obtained from the polarization curve and Fig. 2 shows the corrosion rate measurements set up. The corrosion cell consisted of a saturated calomel reference electrode (SCE), counter electrode (graphite rod) and the reinforcing steel embedded in concrete specimens acted as the working electrode. The potentiodynamic polarization test was performed using scanning potential $-200 \mathrm{mV}$ through $1,200 \mathrm{mV}$, with a scan rate of $1 \mathrm{mV} / \mathrm{s}$. The data were recorded for a fixed duration of $1 \mathrm{hr}$ at ambient temperature. The polarization curve was obtained as the relationship between corrosion potential and current density. Final

Table 1 Mix proportion and compressive strength of concrete.

\begin{tabular}{c|c|c|c|c|c|c}
\hline Concrete mix no. & Water $\left(\mathrm{kg} / \mathrm{m}^{3}\right)$ & Cement $\left(\mathrm{kg} / \mathrm{m}^{3}\right)$ & Sand $\left(\mathrm{kg} / \mathrm{m}^{3}\right)$ & Coarse aggregate $\left(\mathrm{kg} / \mathrm{m}^{3}\right)$ & w/c $(\%)$ & Compressive strength $(\mathrm{MPa})$ \\
\hline \hline 1 & 187 & 287.7 & 775 & 1,009 & 65 & 20 \\
\hline 2 & 187 & 415.5 & 659 & 1,022 & 45 & 46 \\
\hline
\end{tabular}

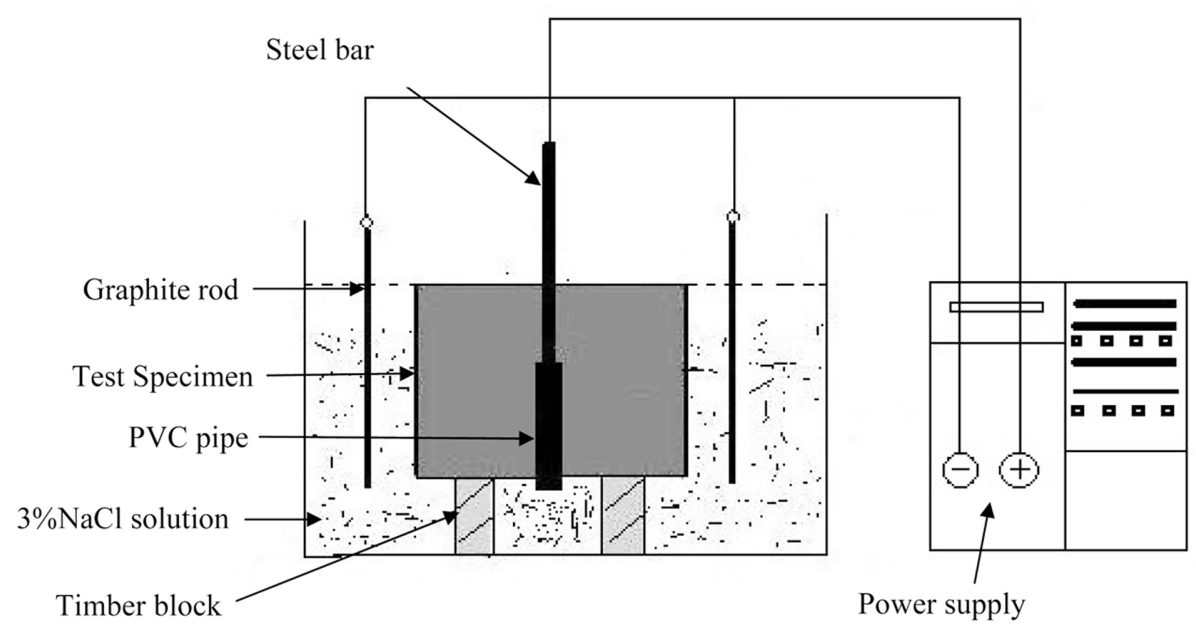

Fig. 1 Accelerated corrosion test set-up. 


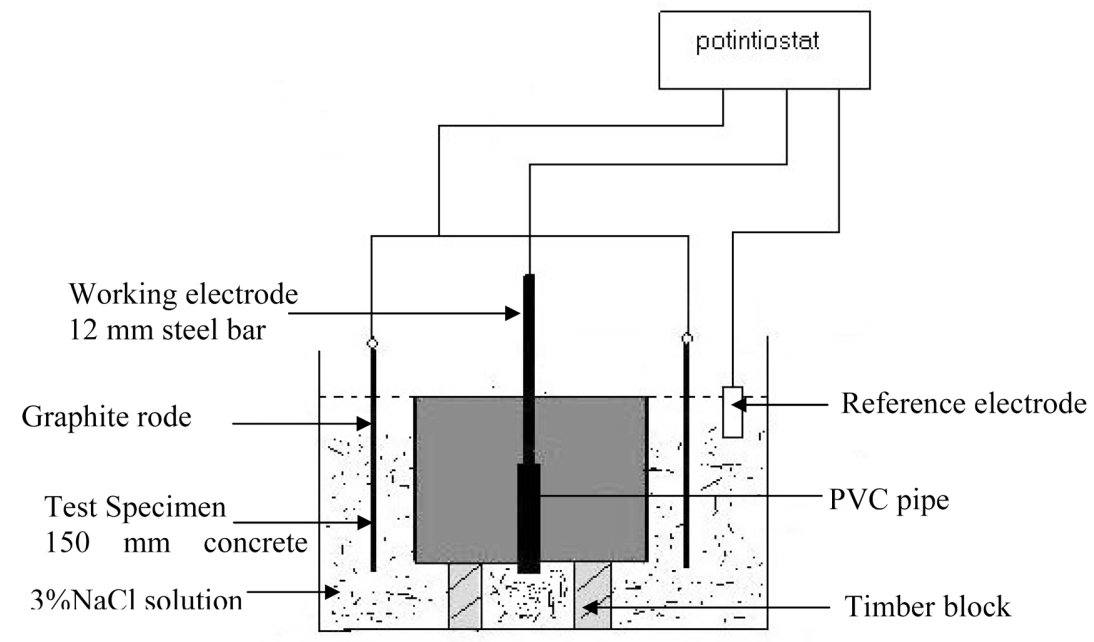

Fig. 2 Corrosion rate measurements set-up.

corrosion rate measurements, C.R., of steel were obtained from Eq. (3) below $^{20}$ :

$$
\text { C.R. }(\text { mpy })=\frac{0.129 I_{\text {Corr }} W}{D A}
$$

where $W$ is the atomic weight of steel (56 for iron), $D$ is the density of steel in $\mathrm{gm} / \mathrm{cm}^{3}, A$ is the exposed surface area in $\mathrm{cm}^{2}$ and $I_{\text {Corr }}$ is the corrosion current density in $\mu \mathrm{A} / \mathrm{cm}^{2}$.

After finishing the electrochemical measurements, the pull-out test was then conducted according to the RILEM technical recommendation $^{21}$ using the Instron testing machine as illustrated in Fig. 3. A dial gauge was used to measure the slip between the steel bar and concrete at a constant loading rate of $0.5 \mathrm{~mm} / \mathrm{min}$. At the end of each pull-out test the concrete specimens were broken out and the steel rebar was extracted from concrete for morphological investigation.

\section{Expermental results}

\subsection{Corrosion test results}

\subsubsection{Effect of $\mathrm{CN}$ concentration on corrosion rate}

Figure 4 shows the corrosion behaviour of mild steel in concrete mixed with 0, 2 and $4 \% \mathrm{CN}$, having $20 \mathrm{MPa}$ compressive strength in $3 \% \mathrm{NaCl}$ solution after corrosion acceleration for 1,7 and 15 days, respectively. Table 3 also presents the free corrosion potential, $\mathrm{E}_{\text {corr }}(\mathrm{mV})$, and corresponding corrosion current density, $\mathrm{I}_{\text {corr }}$ $\left(\mu \mathrm{A} / \mathrm{cm}^{2}\right)$, for test specimens as obtained from the potentiodynamic polarisation data. The addition of $\mathrm{CN}$ to concrete shifted the free corrosion potential to a less noble state from $-469 \mathrm{mV}$ (without $\mathrm{CN})$ to $-441 \mathrm{mV}(2 \% \mathrm{CN})$ and $-441 \mathrm{mV}(4 \% \mathrm{CN})$, and the corresponding corrosion current density decreased from $55.6 \mu \mathrm{A}$ $\mathrm{cm}^{2}$ to $44.2 \mu \mathrm{A} / \mathrm{cm}^{2}$ and $-39.8 \mu \mathrm{A} / \mathrm{cm}^{2}$, respectively, after 1 day of corrosion acceleration. A similar pattern was observed as the accelerated time extended to 7 days as indicated in Table 3 and Fig. 4(b). After 15 days of corrosion acceleration the specimen containing $2 \% \mathrm{CN}$ showed less corrosion resistance than the specimen without $\mathrm{CN}$ as a slight increase in the corrosion current density from 823 to $841 \mu \mathrm{A} / \mathrm{cm}^{2}$ was noted. However, specimens containing $4 \% \mathrm{CN}$ showed better corrosion resistance as can be seen in Table 3 and Fig. 4(c).

Figure 5 and Table 3 present the polarization results of steel bars in concrete specimens of compressive strength $46 \mathrm{MPa}$, mixed with $0 \%, 2 \%$ and $4 \% \mathrm{CN}$ after corrosion acceleration of 1,7 and 15 days, respectively. After 1 day of exposure to accelerated corrosion, the rebar in concrete mixed with $2 \%$ and $4 \% \mathrm{CN}$ showed an

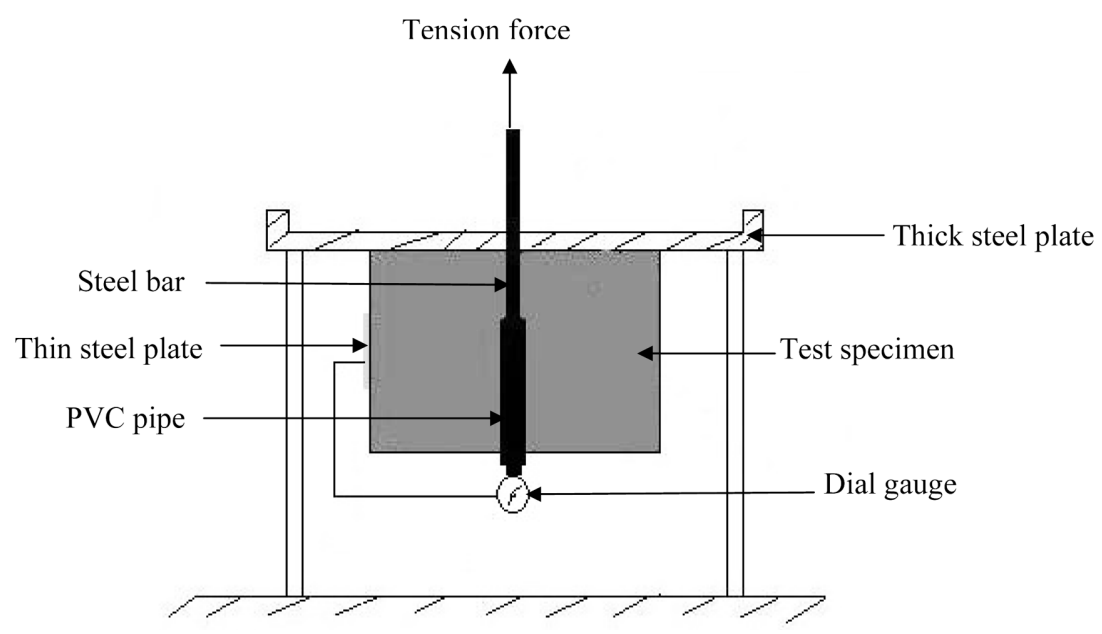

Fig. 3 Pull-out test set up. 


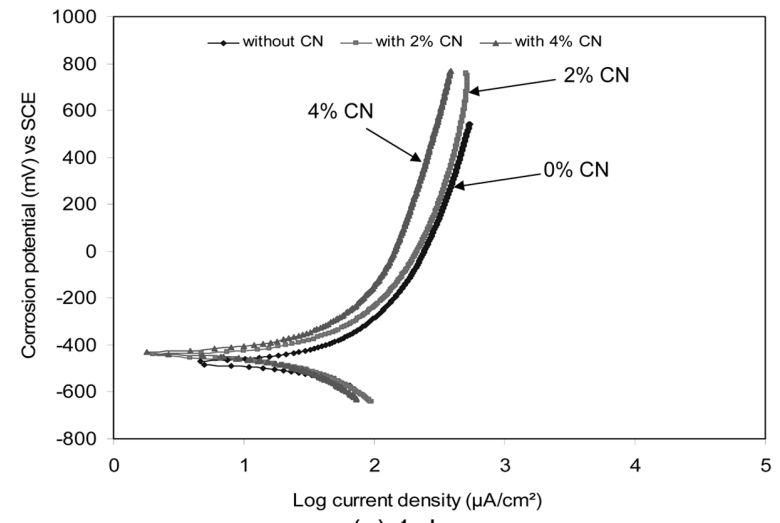

(a) 1 day

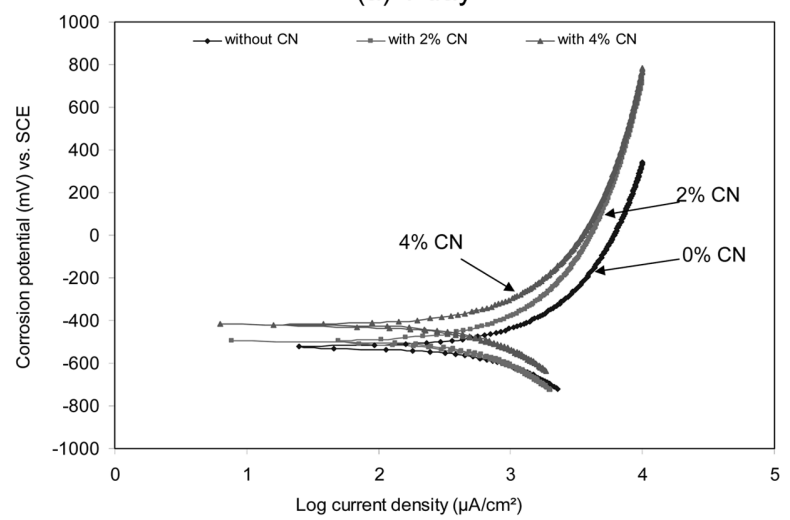

(b) 7 days

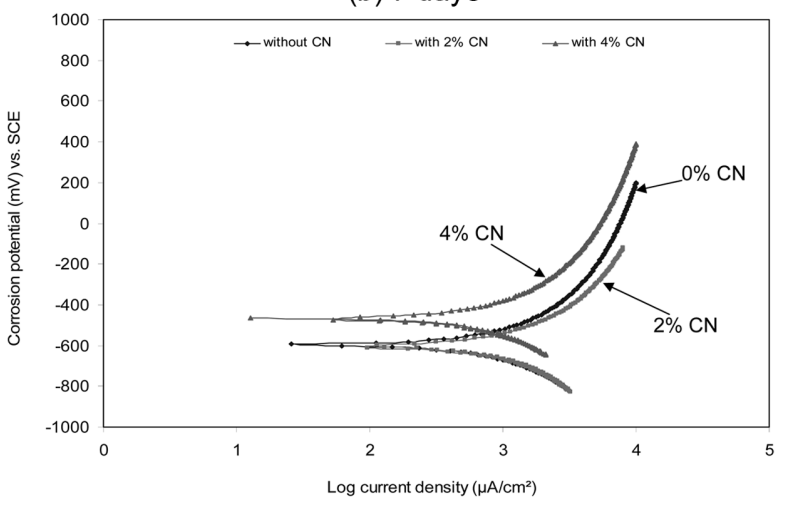

(c) 15 days

Fig. 4 Effect of $\mathrm{CN}$ concentration on corrosion rates of steel in concrete having $20 \mathrm{MPa}$ compressive strength for various exposure periods.

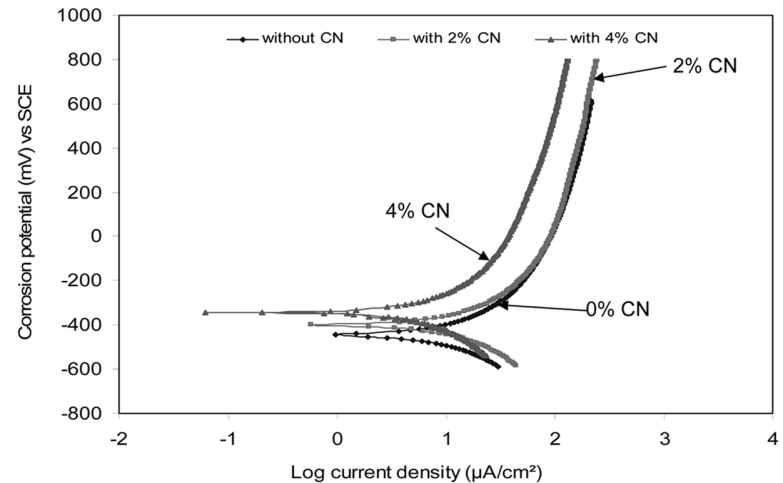

(a) 1 day

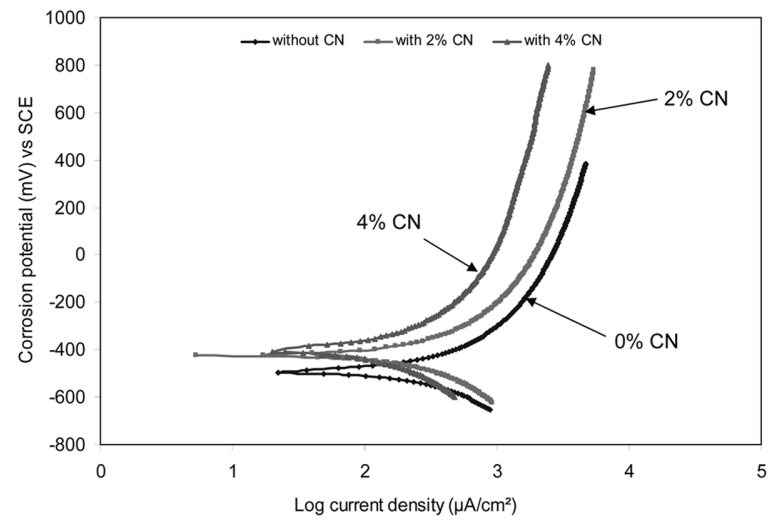

(b) 7 days

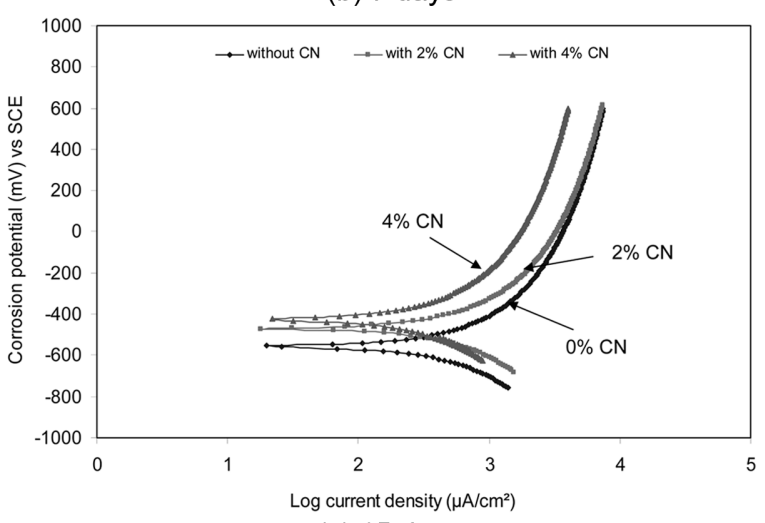

(c) 15 days

Fig. 5 Effect of $\mathrm{CN}$ concentration on corrosion rates of steel in concrete having $46 \mathrm{MPa}$ compressive strength for various exposure periods.

Table 3 Free corrosion potential and corresponding corrosion current density for various concrete specimens.

\begin{tabular}{|c|c|c|c|c|c|}
\hline Concrete strength $(\mathrm{MPa})$ & Accelerated corrosion period & & Without CN & $2 \% \mathrm{CN}$ & $4 \% \mathrm{CN}$ \\
\hline \multirow{6}{*}{20} & \multirow{2}{*}{1 day } & $\mathrm{E}_{\text {corr }}(\mathrm{mV})$ & -469 & -441 & -430 \\
\hline & & $\mathrm{I}_{\text {corr }}\left(\mu \mathrm{A} / \mathrm{cm}^{2}\right)$ & 55.6 & 44.2 & 39.8 \\
\hline & \multirow{2}{*}{7 days } & $\mathrm{E}_{\mathrm{corr}}(\mathrm{mV})$ & -523 & -492 & -414 \\
\hline & & $\mathrm{I}_{\text {corr }}\left(\mu \mathrm{A} / \mathrm{cm}^{2}\right)$ & 725 & 600 & 540 \\
\hline & \multirow{2}{*}{15 days } & $\mathrm{E}_{\text {corr }}(\mathrm{mV})$ & -650 & -610 & -462 \\
\hline & & $\mathrm{I}_{\text {corr }}\left(\mu \mathrm{A} / \mathrm{cm}^{2}\right)$ & 823 & 841 & 591 \\
\hline \multirow{6}{*}{46} & \multirow{2}{*}{1 day } & $\mathrm{E}_{\mathrm{corr}}(\mathrm{mV})$ & -443 & -397 & -350 \\
\hline & & $\mathrm{I}_{\text {corr }}\left(\mu \mathrm{A} / \mathrm{cm}^{2}\right)$ & 15.2 & 13.4 & 11.3 \\
\hline & \multirow{2}{*}{7 days } & $\mathrm{E}_{\text {corr }}(\mathrm{mV})$ & -550 & -490 & -410 \\
\hline & & $\mathrm{I}_{\text {corr }}\left(\mu \mathrm{A} / \mathrm{cm}^{2}\right)$ & 180 & 165 & 155 \\
\hline & \multirow{2}{*}{15 days } & $\mathrm{E}_{\text {corr }}(\mathrm{mV})$ & -730 & -600 & -480 \\
\hline & & $\mathrm{I}_{\text {corr }}\left(\mu \mathrm{A} / \mathrm{cm}^{2}\right)$ & 562 & 398 & 300 \\
\hline
\end{tabular}

Note) $\mathrm{E}_{\text {corr }}=$ free corrosion potential and $\mathrm{I}_{\text {corr }}=$ corrosion current density. 
improvement in the corrosion behaviour compared with the steel bar in concrete without $\mathrm{CN}$ as the corrosion potential moved in more noble direction (from $-443 \mathrm{mV}$ to $-397 \mathrm{mV}$ and $-350 \mathrm{mV}$ ) and there was a decrease in corrosion current density from $15.2 \mu \mathrm{A} / \mathrm{cm}^{2}$ to $13.4 \mu \mathrm{A} / \mathrm{cm}^{2}$ and $11.3 \mu \mathrm{A} / \mathrm{cm}^{2}$, respectively. A similar trend was also observed when periods of accelerated corrosion extended to 7 and 15 days, see Table 3 and Fig. 5(a) and (b); the steel bars in concrete mixed with $2 \% \mathrm{CN}$ had better corrosion resistance than control specimen (without $\mathrm{CN}$ ) and this improvement in the corrosion resistance was even more pronounced in specimens containing $4 \% \mathrm{CN}$.

It appears that low concentration of $\mathrm{CN}(2 \%)$ in low strength concrete of $20 \mathrm{MPa}$ compressive strength caused less corrosion resistance at long time of exposure to $3 \% \mathrm{NaCl}$ solution as concrete allowed sufficient chloride ingress into steel bar surface reducing the efficiency of $\mathrm{CN}$. However, the presence of $2 \% \mathrm{CN}$ in higher strength concrete had the ability to provide better protection even at longer exposure time of 15 days.

\subsubsection{Effect of exposure time on corrosion rate}

Figure 6(a) shows the polarization curves for steel bars embedded in concrete mix with $2 \% \mathrm{CN}$ and having $20 \mathrm{MPa}$ compressive strength after 1,7 and 15 days of accelerated corrosion. Seven days of corrosion acceleration caused an increase in corrosion current density to $600 \mu \mathrm{A} / \mathrm{cm}^{2}$ (compared with $44.2 \mu \mathrm{A} / \mathrm{cm}^{2}$ at 1 day of corrosion acceleration). When the acceleration time extended to 15 days severe corrosion occurred with a shift in free corrosion potential in a more active direction to $-609 \mathrm{mV}$ and a large deviation in polarization curve to current density of $841 \mu \mathrm{A} / \mathrm{cm}^{2}$, indicating reduced efficiency of this rather small amount of $\mathrm{CN}$ for

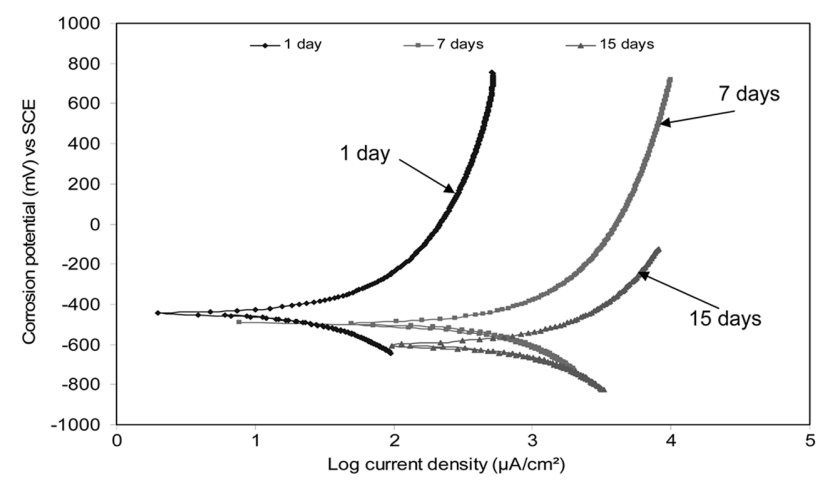

(a) $2 \% \mathrm{CN}$

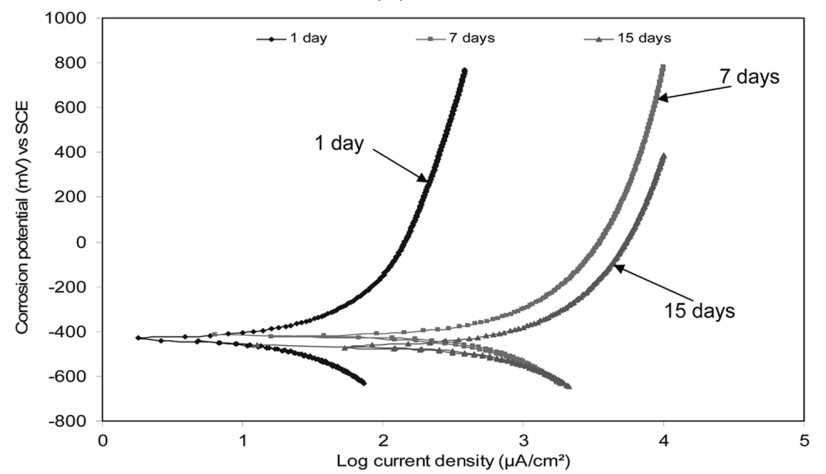

(b) $4 \% \mathrm{CN}$

Fig. 6 Effect of corrosion acceleration time on mild steel in concrete having $20 \mathrm{MPa}$ compressive strength for various $\mathrm{CN}$ concentrations. longer exposure time as the ratio of chloride to nitrite around steel bar increased.

Figure 6(b) gives the polarization curves of steel bars in concrete mix with $4 \% \mathrm{CN}$ and having $20 \mathrm{MPa}$ compressive strength at different accelerated times of 1, 7 and 15 days. Extending the corrosion acceleration time from 1 day to 7 days had the effect of increasing corrosion current density from 39.8 to $540 \mu \mathrm{A} / \mathrm{cm}^{2}$. Further exposure up to 15 days increased the corrosion current density to $591 \mu \mathrm{A} / \mathrm{cm}^{2}$ and hence reduced corrosion resistance.

Figure 7 compares the polarization curves of steel bars in concrete of strength $46 \mathrm{MPa}$ mixed with $2 \% \mathrm{CN}$ (Fig. 7(a)) and 4\% $\mathrm{CN}$ (Fig. 7(b)) for three different corrosion acceleration times 1, 7 and 15 days. The accelerated corrosion duration of 7 days had the effect of shifting the corrosion potential in a less noble direction and increasing the corrosion current density compared with 1 day of corrosion acceleration. After 15 days of corrosion acceleration, a further shift in corrosion potential to a more active direction and an increase in corrosion current density were also observed.

Figure 8 illustrates the corrosion rate values for 20 and $46 \mathrm{MPa}$ specimens with 0,2 and $4 \% \mathrm{CN}$ after three durations of accelerated corrosion. At exposure periods of 1 and 7 days, it is clear that for both concrete mixes the corrosion rate decreased with added $\mathrm{CN}$. At short time of exposure of 1 day and low concrete strength of $20 \mathrm{MPa}$, the range of corrosion rate reduced from $2.25 \mathrm{mpy}$ $(0 \% \mathrm{CN})$ to $1.61 \mathrm{mpy}(4 \% \mathrm{CN})$, and from $0.61 \mathrm{mpy}(0 \% \mathrm{CN})$ to $0.45 \mathrm{mpy}(4 \% \mathrm{CN})$ for the $46 \mathrm{MPa}$ concrete strength. As accelerated corrosion extended to 7 days, the corrosion rate varied from $29.5 \mathrm{mpy}(0 \% \mathrm{CN})$ to $22 \mathrm{mpy}(4 \% \mathrm{CN})$ for concrete having strength of $20 \mathrm{MPa}$, and from $15.3 \mathrm{mpy}(0 \% \mathrm{CN})$ to $6.32 \mathrm{mpy}(4 \% \mathrm{CN})$ for the $46 \mathrm{MPa}$ concrete strength.

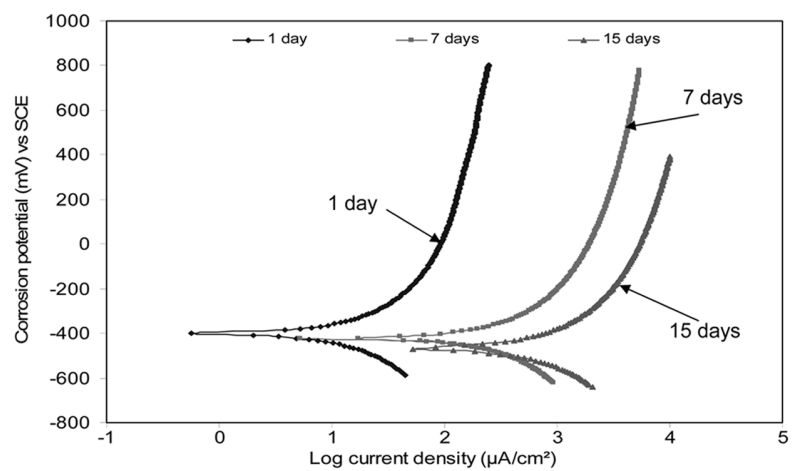

(a) $2 \% \mathrm{CN}$

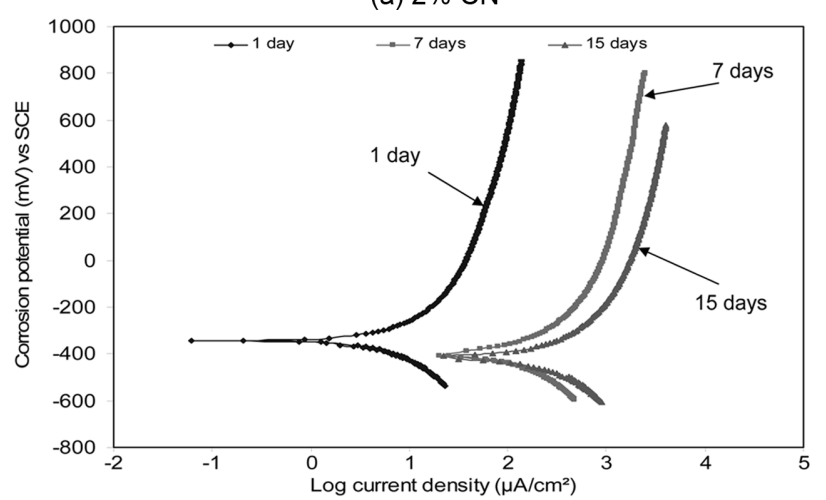

(b) $4 \% \mathrm{CN}$

Fig. 7 Effect of corrosion acceleration time on mild steel in concrete having $46 \mathrm{MPa}$ compressive strength for various $\mathrm{CN}$ concentrations. 


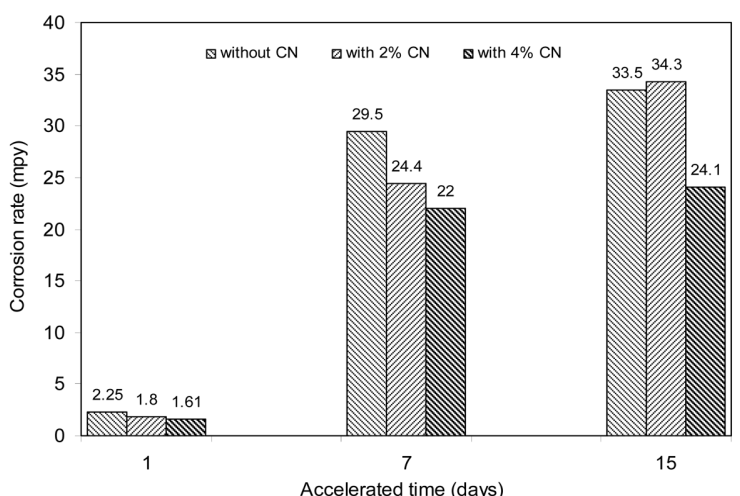

(a) $20 \mathrm{MPa}$ compressive strength

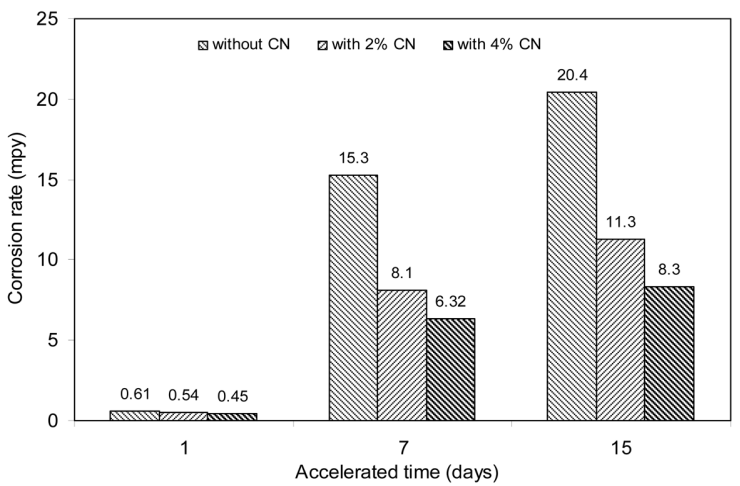

(b) $46 \mathrm{MPa}$ compressive strength

Fig. 8 Corrosion rates versus accelerated corrosion time for different concrete mixes.

Further corrosion acceleration to 15 days showed the same trend as that after 7 days except in case of concrete specimen of $20 \mathrm{MPa}$ compressive strength containing $2 \% \mathrm{CN}$ where the highest corrosion rate of 34.3 mpy was recorded. In general, the corrosion rate followed the trend that as the $\mathrm{CN}$ content increased, the corrosion rate decreased. This can be attributed to the passivity achieved as the increase in $\mathrm{CN}$ allowed less chloride concentration to be in contact with steel bars because of the formation of a protective film on steel surface. The lowest corrosion rate values for the same exposure time were recorded for concrete mixed with $4 \% \mathrm{CN}$, as indicated in Fig. 8.

\subsection{Mechanical test results}

\subsubsection{Effect of $\mathrm{CN}$ concentration on steel-concrete bond} strength

Figures 9 and 10 show the calculated bond stress $(=P / \pi d l$, where $P=$ applied load, $d=$ steel bar diameter and $l=$ bonded length) against the end slip of steel bar in concrete with 0,2 and $4 \% \mathrm{CN}$ after 1, 7 and 15 days of corrosion acceleration. In each pull-out test, the bond-slip at the free bar end was measured at various load increments up to failure.

At minimum exposure of 1 day the relationship between bond stress and end slip is characterized by three zones. The first zone exhibited very little increase in slip with the load increase up to a point below the maximum bond strength. The second zone is identified by a slip increase with the load increase until ultimate bond strength, beyond which there was a gradual increase in bond slip with the load decrease. A slight reduction in bond strength was observed when the specimens containing $\mathrm{CN}$ tested with respect to the control specimen (without $\mathrm{CN}$ ); see Fig. 9(a). Fur-

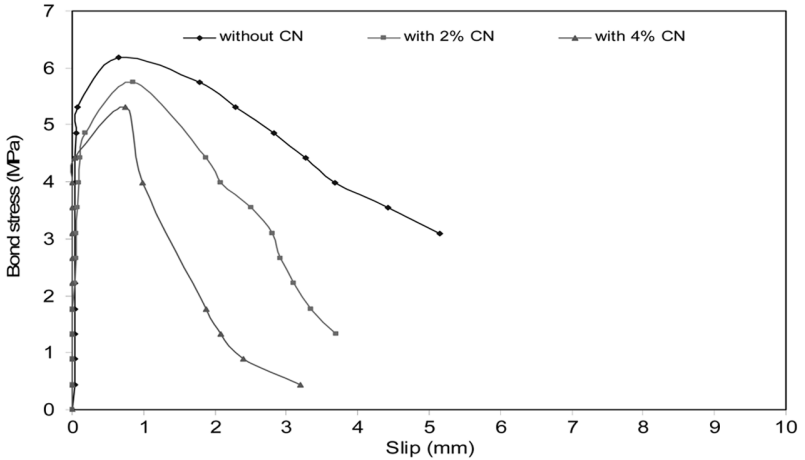

(a) 1 day

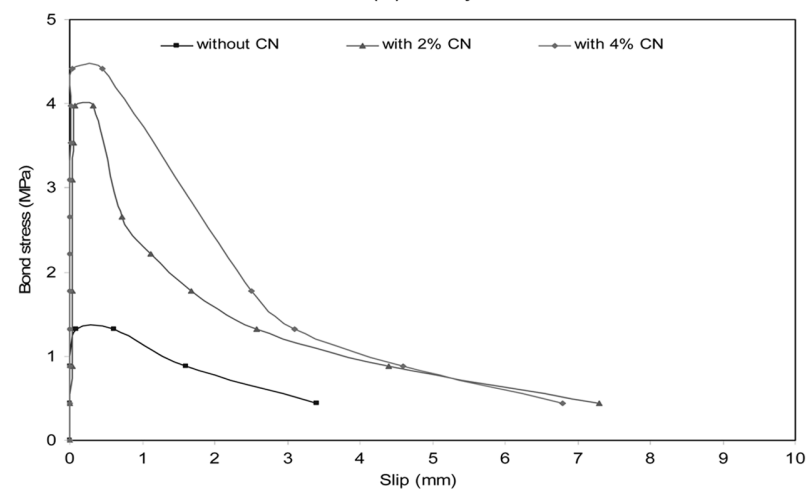

(b) 7 days

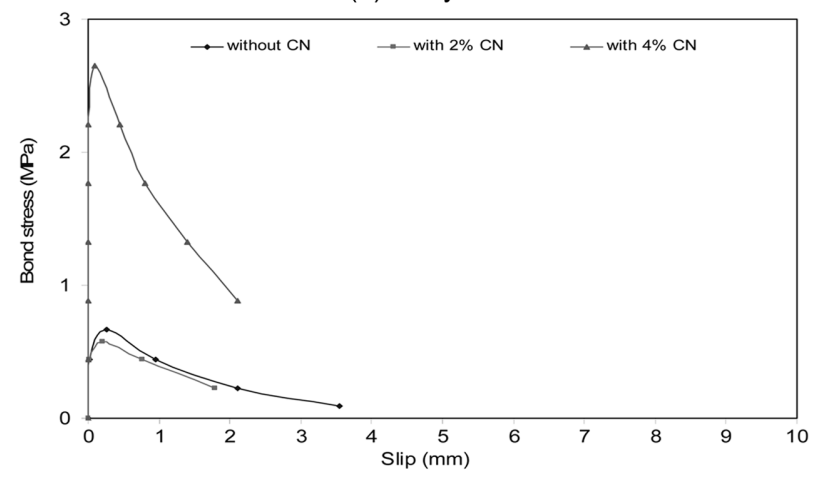

(c) 15 days

Fig. 9 Bond stress versus slip for $20 \mathrm{MPa}$ concrete strength with and without $\mathrm{CN}$.

ther corrosion acceleration duration of 7 and 15 days showed different characteristics of load-slip relationship, that was approximately linear up to the maximum bond strength beyond which a sharp decrease in load against bond slip increase was observed. In addition, a significant enhancement of steel concrete bond strength was achieved with the increase in $\mathrm{CN}$ content up to $4 \%$ for longer corrosion exposure of 7 and 15 days as can be observed in Fig. 9(b) and (c).

The bond stress-slip relationship of steel bar in concrete mixed with and without $\mathrm{CN}$ and having $46 \mathrm{MPa}$ compressive strength is displayed in Figure 10. A linear relationship followed up to a point below the ultimate bond strength, thereafter there was a sudden decrease in bond stress with a gradual increase in bond slip for specimens exposed to 1 day of corrosion acceleration. There was a slight decrease in bond strength at early stage (1 day) of corrosion when $\mathrm{CN}$ added to concrete compared with specimens without $\mathrm{CN}$. As the formation of corrosion products, which at this stage increases, the rebar roughness enhances the friction between the bar and surrounding concrete. Inducing more level of corrosion by 


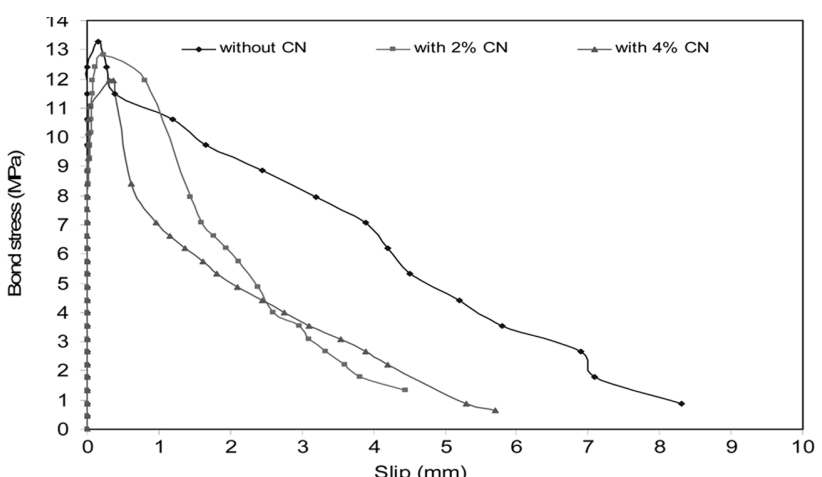

(a) 1 day

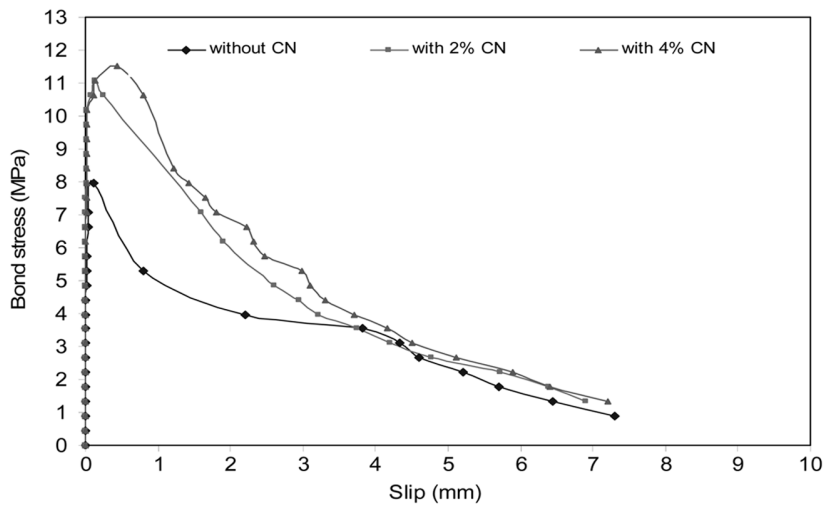

(b) 7 days

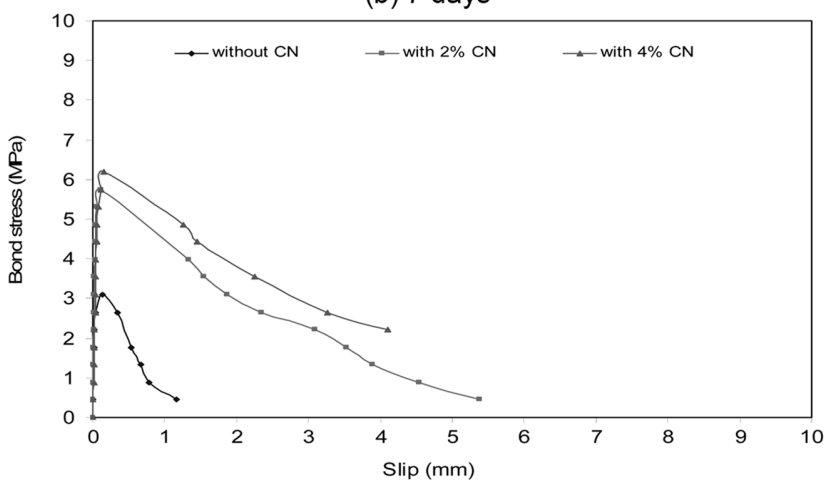

(c) 15 days

Fig. 10 Bond stress versus slip for $46 \mathrm{MPa}$ concrete strength with and without $\mathrm{CN}$.

extending the exposure time to 7 and 15 days, Fig. 10(b) and (c) showed different behaviour as below:

- The presence of $\mathrm{CN}$ increased the bond strength compared with specimens without $\mathrm{CN}$.

- The bond stress-slip curves showed a linear behaviour up to ultimate bond strength and then the bond stress sharply decreased with large increase in slip.

Figure 11 shows the effect of corrosion on steel-concrete bond strength of different concrete mixes. At early stage of accelerated corrosion (1 day) for both concrete mixes the greatest bond strength is achieved for concrete specimens without $\mathrm{CN}$ as the steel surface without $\mathrm{CN}$ has slightly more corrosion products which enhance the bond between steel bar and concrete. With further accelerated corrosion to 7 days the concrete mix with $4 \%$ added $\mathrm{CN}$ showed the greatest bond strength and concrete without $\mathrm{CN}$ showed the lowest bond strength for both concretes. All concrete mixes showed deterioration in bond strength between 1 day and 7 days of corrosion acceleration.

A continuous decrease in bond strength for all concrete mixes

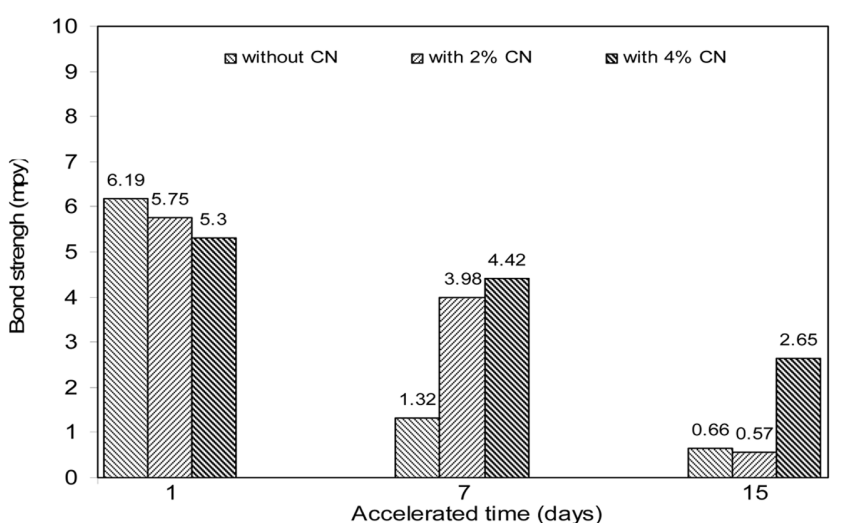

(a) $20 \mathrm{MPa}$ compressive strength

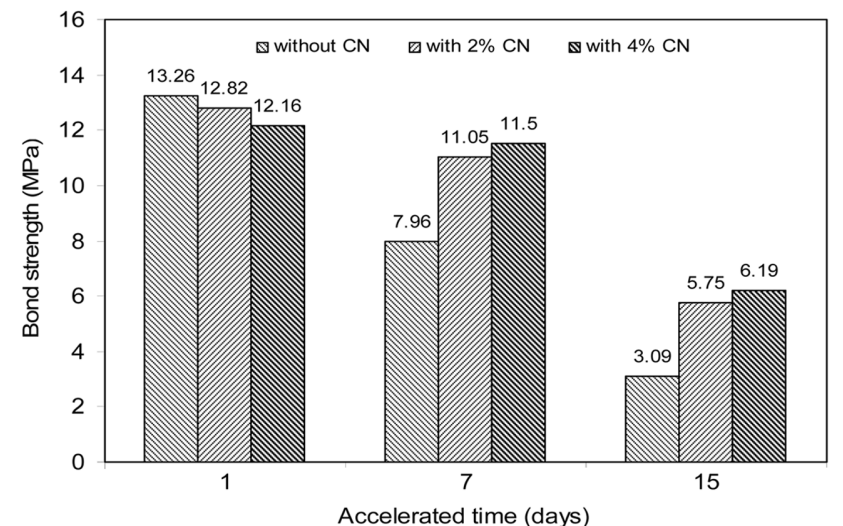

(b) $46 \mathrm{MPa}$ compressive strength

Fig. 11 Effect of $\mathrm{CN}$ on steel-concrete bond strength for various exposure times.

was observed when accelerated corrosion was extended to 15 days. However, the highest deterioration in bond strength for $20 \mathrm{MPa}$ and $46 \mathrm{MPa}$ concrete strengths was recorded for the mix with $2 \% \mathrm{CN}$ and $0 \% \mathrm{CN}$, respectively. On the other hand, the least bond strength deterioration for both concrete mixes was achieved when $4 \% \mathrm{CN}$ inhibitor was added.

\subsection{Morphology investigation results}

The morphology investigation results of steel bars after 15 days of corrosion acceleration in $3 \% \mathrm{NaCl}$ for each concrete mix are presented in this section. Figure 12 shows the conditions of steel bars removed from concrete having $20 \mathrm{MPa}$ compressive strength mixed with $0 \%, 2 \%$ and $4 \% \mathrm{CN}$. The rebar removed from concrete containing $2 \% \mathrm{CN}$ was deeply corroded with higher severe reduction in bar diameter at the top concrete edge side compared with the reference rebar $(0 \% \mathrm{CN})$ as depicted in Fig. 12(a) and (b). This confirms and justifies the high corrosion rate and the lowest steel-concrete bond strength recorded for $2 \% \mathrm{CN}$ concrete specimen. The rebar extracted from concrete with $4 \% \mathrm{CN}$ had uniform oxide rust over the steel surface and less reduction in bar diameter, see Fig. 12(c).

Figure 13 presents the reinforcing steel bars retrieved from 46 MPa compressive strength concrete specimens with $0 \%, 2 \%, 4 \%$ $\mathrm{CN}$. The condition of steel bar surface transformed from localized corrosion in form of large pits and deep grooves along bar length $(0 \% \mathrm{CN})$ to small pits and uniform corrosion rust for rebar removed from $2 \% \mathrm{CN}$ specimen, see Fig. 13(a) and (b). On the other hand, moderate corrosion along the embedded portion of the steel bar was observed on the bar extracted from $4 \% \mathrm{CN}$ concrete 


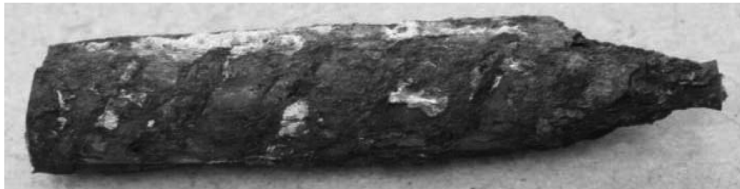

(a) Concrete mixed with zero $\mathrm{CN}$

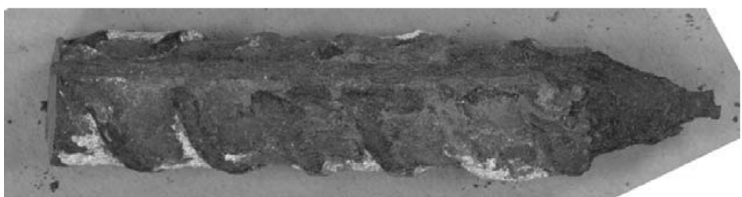

(b) Concrete mixed with $2 \% \mathrm{CN}$

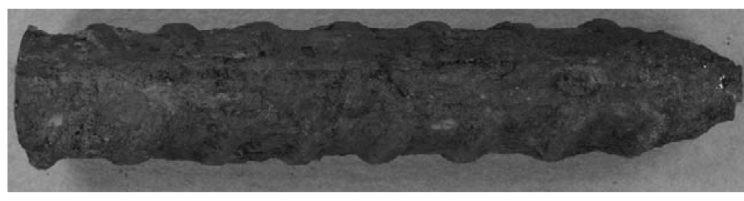

(c) Concrete mixed with $4 \% \mathrm{CN}$

Fig. 12 Macroscopic examination of steel bars in concrete of $20 \mathrm{MPa}$ compressive strength after 15 days of corrosion acceleration.

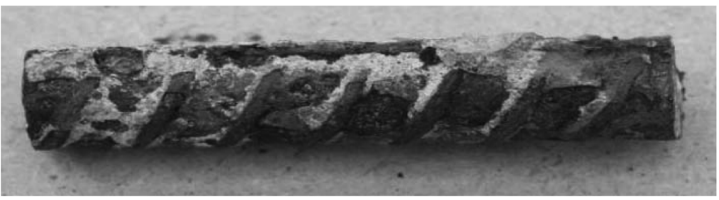

(a) Concrete mixed with zero $\mathrm{CN}$

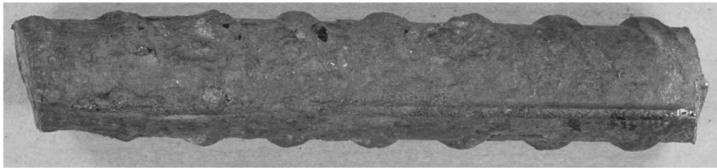

(b) Concrete mixed with $2 \% \mathrm{CN}$

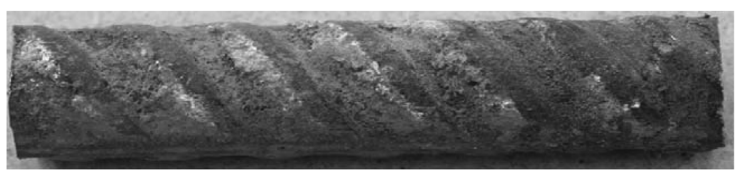

(c) Concrete mixed with $4 \% \mathrm{CN}$

Fig. 13 Macroscopic examination of steel bars in concrete of $46 \mathrm{MPa}$ compressive strength after 15 days of corrosion acceleration.

specimen, Fig. 13(c), indicating that $\mathrm{CN}$ can modify the steel surface and retard chloride induced corrosion.

\section{Discussions}

Test results showed that corrosion resistance of reinforcing steel bar depends on the amount of $\mathrm{CN}$ in concrete mix. A higher content of $\mathrm{CN}$ enhanced the formation of stable ferric oxide film on steel surface and hence restricted the ability of chloride ions to react with ferrous ions to cause pitting corrosion. However, a small amount of $\mathrm{CN}$ (i.e. $2 \%$ of cement weight) may accelerate the corrosion process as it cannot produce sufficient oxide film to resist chloride attack, allowing chloride ions through the passive layer and hence pitting corrosion occurs.

The corrosion rate was low at early age of exposure ( 1 day) because steel was still passive and concrete resistivity was high. The corrosion rate increased with the increase in exposure time due to ingress of chloride in concrete to the steel surface causing breakdown of passivation. The measured data demonstrated that steel corrosion resistance in reinforced concrete specimens having $20 \mathrm{MPa}$ compressive strength improved by an addition of $2 \% \mathrm{CN}$ up to 7 days of corrosion acceleration. Test specimens exhibited less corrosion resistance in presence of $2 \% \mathrm{CN}$ when exposure time extended up to 15 days as more chloride reached the steel surface, interfering the oxide film. In addition, the chloride to nitrite concentration ratio near to the steel surface became so high that the effect of nitrite was therefore vanished. Nevertheless a higher amount of nitrite (4\%) gave better inhibition of corrosion of steel bar. As both nitrite and chloride ions tend to react with ferrous alloys, the amount of nitrite ions can become inhibitive or act in such a way as to plug any pores in any passive film, a key factor in being active in corrosion inhabitation. ${ }^{12,22}$

Accelerated corrosion of reinforced concrete specimens without $\mathrm{CN}$ for 15 days in presence of chloride confirmed the localized corrosion form and severe reduction in diameter of rebar extracted from $20 \mathrm{MPa}$ compressive strength specimen, as well as large pit and grooves along embedded length of rebar removed from $46 \mathrm{MPa}$ compressive strength specimen. This may be due to the electro-migration of the chlorides to induce localized corrosion. On the other hand, uniform corrosion was observed for steel bars removed from concrete specimens containing $4 \% \mathrm{CN}$ for both concrete mixes. However, less corrosion products along embedded bar extracted from $46 \mathrm{MPa}$ compressive strength specimens were observed compared with $20 \mathrm{MPa}$ compressive strength specimens. This implies that the combination of high strength concrete and sufficient amount of $\mathrm{CN}$ appears to be desirable to reduce the chloride-induced steel reinforcement corrosion.

Steel-concrete bond strength was affected by the addition of $\mathrm{CN}$ to concrete mixture for all exposure times. Short exposure time (1 day) caused a slight reduction in bond strength of specimens containing $\mathrm{CN}$ compared with specimens without $\mathrm{CN}$. This is attributed to the slight corrosion layer formed on the steel surface improving the bond strength of specimens without CN. However the presence of $\mathrm{CN}$ can improve the corrosion resistance, producing less steel surface roughness. Exposure of 7 days caused an increase in corrosion products at the bar surface in the form of a flaky layer. The data indicated less deterioration in bond strength in specimens containing $\mathrm{CN}$ as $\mathrm{CN}$ can modify the steel surface by reducing corrosion products and hence improving the steel/ bond strength.

With advanced corrosion stage (15 days) of accelerated corrosion, products at the bar surface were relatively loose; however the results clearly showed the trend of higher bond strength for higher $\mathrm{CN}$ concentration. The $20 \mathrm{MPa}$ compressive strength specimen with $2 \% \mathrm{CN}$ did not follow this trend as a result of high anodiccathodic ratio which accelerated the corrosion process.

\section{Conclusions}

The present study examined the corrosion resistance and steelconcrete bond strength of concrete specimens containing $\mathrm{CN}$ in presence of chlorides. The specimens were immersed in 3\% NaCl solutions and subjected to accelerated corrosion using impressed current for different durations. The experiments included the potentiodynamic polarization curves for corrosion rate measurements and pull-out test for evaluation of bond strength between 
steel and concrete.

The presence of $\mathrm{CN}$ generally makes chloride corrosion less severe. However, $\mathrm{CN}$ has to be present at the reinforcing steel surface in high concentration with respect to the aggressive chloride ions over a long period of time. For low concrete strength and exposure conditions evaluated in this investigation, it was found that a dosage of $2 \% \mathrm{CN}$ was not enough to achieve corrosion protection of steel reinforcement in concrete. However, the combination of high strength concrete and $2 \% \mathrm{CN}$ appears to be a desirable approach to reduce the effect of chloride induced corrosion of steel reinforcement.

At short time (1 day) of exposure, specimens without $\mathrm{CN}$ showed higher bond strength in both concrete mixes than those with $\mathrm{CN}$ because of the effect of surface roughness. Further corrosion acceleration up to 7 and 15 days confirmed the higher concentration of $\mathrm{CN}$, the higher the bond strength in both concrete mixes as $\mathrm{CN}$ modifies the surface, reduces the corrosion activity, and thereby lowers the deterioration of steel-concrete bond strength. However, concrete specimens having $20 \mathrm{MPa}$ compressive strength with $2 \% \mathrm{CN}$ recorded the highest deterioration in bond strength after 15 days of corrosion acceleration due to high anodic-cathodic ratio at the rebar level. Morphology analysis also indicated that incorporation of sufficient $\mathrm{CN}$ corrosion inhibitor in concrete modified the steel surface texture, and retarded chlorideinduced corrosion.

\section{References}

1. Page, C. L. and Treadaway, K. W. J., "Aspects of Electrochemistry of Steel in Concrete," Nature, Vol. 297, 1982, pp. 109 116.

2. Valcarece, M. B. and Vazquez, M., "Carbon Steel Passivity Examined in Alkaline Solutions: The Effect of Chloride and Nitrite Ions," Electrochimica Acta, Vol. 53, 2008, pp. 5007 5015.

3. Cabrera, J., "Deterioration of Concrete due to Reinforcement Steel Corrosion," Cement and Concrete Composites, Vol. 18, 1996, pp. 47 59.

4. Chung, L., Kim, J. H., and Yi, S. T., "Bond Strength Prediction for Reinforced Concrete Members with Highly Corroded Reinforcing bars," Cement and Concrete Composites, Vol. 30, 2008, pp. 603 611.

5. Rashid, M., Khatun, S., Uddin, S. M., and Nayeem, M. A., "Effect of Strength and Covering on Concrete Corrosion," European Journal of Scientific Research, Vol. 40, 2010, pp. 492 499.

6. Broomfield, J. G, "Corrosion of Steel in Concrete: Understanding, Repair and Investigation," First Edition, E and FN Spon, London, 1997.

7. Saricimen, H. Mohammad, M., Quddus, A., Shameem, M. and Barry, M. S., "Effectiveness of Concrete Inhibitors in Retarding Rebar Corrosion," Cement and Concrete Composites, Vol. 24, 2002, pp. 89 100.

8. Ngala, V. T., Page, C. L., and Page, M. M., "Corrosion Inhibitor Systems for Remedial Treatment of Reinforced
Concrete. Part 1: Calcium Nitrite," Corrosion Science, Vol. 44, 2002, pp. 2073 2087.

9. Berke, N. S. and Hicks, M., "Predicting Long-Term Durability of Steel Reinforced Concrete with Calcium Nitrite Corrosion Inhibitor," Cement and Concrete Composites, Vol. 26, 2004, pp. 191 198.

10. Civjan S. A., Lafave J. M., Trybulski, J., Lovett, D., Lima, J., and Pfeifer, D. W., "Effectiveness of Corrosion Inhibiting Admixture Combinations in Structural Concrete," Cement and Concrete Composites, Vol. 27, 2005, pp. 688 703.

11. Reou, J. S. and Ann, K. Y., "The Electrochemical Assessment of Corrosion Inhibition Effect of Calcium Nitrite in Blended Concretes," Material Chemistry and Physics, Vol. 109, 2008, pp. 526 533.

12. Ormellese, M., Berra, M., Bolzoni, F. and Pastore, T., "Corrosion Inhibitors for Chlorides Induced Corrosion in Reinforced Concrete Structures," Cement and Concrete Research, Vol. 36, 2006, pp. 536 547.

13. Berke, N. S. and Rosenberg, A., "Technical Review of Calcium Nitrite Corrosion Inhibitors in Concrete," Transportation Research Record, No. 1211, Washington, 1989, pp. 18 27.

14. James, M. and Gaidis, "Chemistry of Corrosion Inhibitors," Cement and Concrete Composites, Vol. 26, 2004, pp. 181 189.

15. Al-Moudi, O. S. B., Maslehuddin, M., Lashari, A. N., and Almusallam, A. A., "Effectiveness of Corrosion Inhibitors," Cement and Concrete Composites, Vol. 25, 2003, pp. 439 449.

16. Ann, K. Y, Jung, H. S. Kim, S. S., and Moon, H. Y., "Effect of Calcium Nitrite-Based Corrosion Inhibitor in Preventing Corrosion of Embedded Steel in Concrete," Cement and Concrete Research, Vol. 36, 2006, pp. 530 535.

17. Trepanier, S. M., Hope, B. B., and Hansson, G. M., "Corrosion Inhibitors in Concrete: Part III. Effect on Time to Chloride-Induced Corrosion in Initiation and Subsequent Corrosion Rates of Steel in Concrete," Cement and Concrete Research, Vol. 31, 2001, pp. 713 718.

18. Al-Mehthel, M., Al-Dulaijan, S., Al-ldi, S. H., Shameem, M., and Ali, M. R., "Performance of Generic and Proprietary Corrosion Inhibitors in Chloride-Contaminated Silica Fume Cement Concrete," Construction and Building Materials, Vol. 23, 2009, pp. 1768 1774.

19. El Maaddawy, T. A. and Soudki, K. A., "Effectiveness of Impressed Current Technique to Simulate Corrosion of Steel Reinforcement in Concrete," Journal of Materials in Civil Engineering, Vol. 15, 2003, pp. 41 47.

20. Trethewey, K. T. and Chamberlain, J., Corrosion for Science and Engineering, Second Edition, Longman, UK, 1995.

21. RILEM Technical Recommendations, Bond Test for Reinforcement Steel. 2. Pull-out test, TC9-RC, 1983.

22. Afolabi, A. S., "Synergistic Inhibition of Potassium Chromate and Sodium Nitrite on Mild Steel in Chloride and Sulphide Media," Leonardo Electronic Journal of Practices and Technologies, Vol. 6, 2007, pp. 143 154. 